ON THE RECORD

“The station is like an old suitcase whose handle is missing... it's totally useless, but you just can't bear to part with it."

A former space explorer gets sentimental about the ailing International Space Station

\section{SCORECARD}

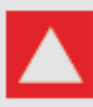

Pine trees

Australian forestry

authorities have netted

around US $\$ 1$ million by auctioning off some ancient trees. Nearly 300 cuttings taken from Wollemi pines, rare fossil trees that grow in a secretgrove in the mountains near Sydney, were sold by Sotheby's on 230ctober.

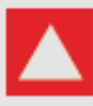

Giant squid

Actor and wannabe rock star Kevin Baconhas penned a song to honour the giant squid, photographed last month by Japanese scientists.

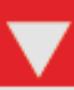

Consumption Disease experts are speculating that tuberculosis and infer tility were partly to blame for the gloomy view of humanity displayed by author George Orwellin his dystopic novel 1984

\section{NUMBER CRUNCH}

\section{Hurricane Wilma}

On 18 October, Hurricane Wilma screamed into life, just two months after Hurricane Katrinadevastated the US Gulf Coast region. By the time Wilma hit the Yucatan Peninsula of Mexico, on 210ctober, it had set a record for the strongest hurricane ever to rise from the Atlantic Basin.

\section{2 millibars was the} record-setting low pressure reached by Wilma at its peak.

\section{8 millibars was the} previous record for Atlantic hurricane intensity, set by Hurricane Gilbert in 1988.

870 millibars was the peak intensity of 1979's Super Typhoon Tip, which holds the record for the strongest and largest cyclone.

\author{
IMAGE \\ UNAVAILABLE \\ FOR COPYRIGHT \\ REASONS
}

\title{
Trial aims to measure social effects of choosing babies' sex
}

\section{WASHINGTON DC}

US doctors have launched a clinical trial to assess the effects of allowing couples to select whether they will have a boy or a girl.

Doctors can use a technology called preimplantation genetic diagnosis (PGD) to examine the sex of embryos that they create by assisted reproduction. Couples then select male or female embryos to implant in the mother's uterus, but the practice is controversial and banned in a number of countries.

Sandra Carson and two colleagues at Baylor College of Medicine in Houston, Texas, started their trial last month,

"We can sanction and remove members who don't obey ethics statements." after nine years of consultations with their institutional review board. The doctors have a waiting list of at least 50 couples, but they will only enroll those who already have a child, and want to have a child of the opposite sex - an approach referred to as 'family balancing.'

An experimental technique called sperm sorting is currently being tested to see whether it can reliably create embryos of a desired sex. But Carson says no one has examined what happens when couples use PGD, a more established tool, to choose an embryo's sex for nonmedical reasons.

The practice, known as 'social sex selection', is thought to be common in the United States. One study found that almost $3 \%$ of PGD procedures, which are performed thousands of times a year, were used to choose a child's sex (K. Sermon et al. Hum. Reprod. 20, 19-34; 2005). But countries such as Britain and Canada have banned the practice owing to public concerns that it could lead to discrimination against women.

"There are still a lot of questions in people's minds about whether this is something that should be pursued," says Robert Brzyski, a fertility doctor at the University of Texas Health Science Center in San Antonio. Brzyski says 